\title{
Tropical Vegetation and Land Cover Mapping Using LiDAR
}

\author{
DOI: 10.18196/pt.2019.088.8-18
}

\author{
Mohammad Nurcholis ${ }^{1 *}$, Iwan Qodar Himawan ${ }^{2}$, Syintianuri Intan Wijayanti ${ }^{1}$, \\ Ayu Darmaristianti ${ }^{2}$ \\ ${ }^{1}$ University of National Development "Veteran" Yogyakarta, Jl. SWK 104 (Lingkar Utara), Condongcatur, Yogyakarta 55283, Indonesia \\ ${ }^{2}$ PT ASI Pudjiastuti Geosurvey, Jl. Ki Mangunsarkoro No.21, Menteng, Jakarta, 10310, Indonesia \\ *Corresponding author, email:nurcholis@upnyk.ac.id
}

\begin{abstract}
LiDAR (Light Detection and Ranging) is a system of active remote sensing technology using a laser beam that has an invisible wave (Infrared) that can penetrate the leaf gap to produce topographic characteristics of the land surface. The research locations were in Tunas Baru Village Sekernan District, Muaro Jambi Regency, Jambi Province. The purpose of this study was to apply Airborne LiDAR technology along with interpretations in agriculture, especially land cover vegetation mapping in Jambi Province, which is a province that has a fairly extensive forest area. Speaking of that situation, a land cover map and classification are needed to find out which vegetation is dominant in the area. The data needed in this professional work class were DEM, DSM and orthophoto data to be processed into CHM (dataCrown Height Model) in order to facilitate digitization in determining density classes. At the same time, orthophoto was used to digitize the classification of vegetation types, which will produce output in the form of a map of land cover in Tunas Baru Village, Sekernan District, Muaro Jambi Regency, Jambi Province.
\end{abstract}

Keywords: Density, LiDAR, Ground cover, Vegetation

\section{ABSTRAK}

LiDAR(Light Detection and Ranging) adalah sistem teknologi penginderaan jauh aktif menggunakan sinar laser yang memiliki gelombang tak terlihat (Infra merah) yang dapat menembus celah daun untuk menghasilkan karakteristik topografi permukaan tanah. Lokasi penelitian berada di Desa Tunas Baru Kecamatan Sekernan, Kabupaten Muaro Jambi, Provinsi Jambi. Tujuan dari penelitian ini adalah untuk menerapkan teknologi Airborne LiDAR bersama dengan interpretasi di bidang pertanian, khususnya pemetaan vegetasi tutupan lahan di Provinsi Jambi yang merupakan provinsi yang memiliki wilayah hutan yang cukup luas. Berbicara tentang situasi itu, peta tutupan lahan dan klasifikasi diperlukan untuk mengetahui vegetasi mana yang dominan di daerah tersebut. Data yang dibutuhkan dalam kelas kerja profesional ini adalah data DEM, DSM, dan ortofoto untuk diolah menjadi CHM (dataCrown Height Model) untuk memfasilitasi digitalisasi dalam menentukan kelas kepadatan. Pada saat yang sama, orthophoto digunakan untuk mendigitalkan klasifikasi tipe vegetasi, yang menghasilkan output dalam bentuk peta tutupan lahan di Desa Tunas Baru, Distrik Sekernan, Kabupaten Muaro Jambi, Provinsi Jambi.

Kata Kunci: Density, LiDAR, Penutup tanah, Vegetasi

\section{INTRODUCTION}

Jambi Province is a province in the island of most people in Jambi province work as farmers in Sumatra, which has abundant natural resources. Areas in Jambi province are dominated by tropical forests and extensive peatland areas in Indonesia. In 2010 the area of oil palm plantation was 588,441 ha (Jambi Province Plantation, 2010). The expansion of oil palm plantations continues to be carried out by local communities to improve the economy. Due to palm oil being so potentially developed in the community, it has led to the conversion of land from natural forests to plantations planted with oil palm and rubber. Rubber plants also enter the second leading commodity after palm oil. Nowadays, oil palm plantations. In this increasingly advanced technological development, such issue is also followed by the conversion of forests and peatlands to become an expansion of industrial estates to increase the production of goods of a company. Almost most of the areas in Jambi Province have peat areas and planted with plantation commodities (Agus and Subiska, 20018).

Along with the development of oil palm plantations, land use in Jambi Province, especially in the author's research area in Muaro Jambi Regency, still needs to be observed, especially on plantations 
which until now still become a superior commodity in that area, in other words land cover in the research area need to be reviewed. Therefore, in this study, the theme was a classification of vegetation and distribution of land cover in the area of Tunas Baru Village, Sekernan District, Muaro Jambi Regency, Jambi Province. Thus, data on vegetation distribution in Muaro Jambi District is needed to make it easier to find out the classification and closure of agricultural land in the area.

\section{LiDAR technology}

LiDAR (Light Detection and Ranging), is one of the remote sensing technologies, known as remote sensing, that has the advantage in the process of acquiring earth elevation measurement data quickly and accurately. In LiDAR technology a day can be used to measure elevations reaching $40 \mathrm{~km} 2$ with a horizontal accuracy of $30 \mathrm{~cm}$ while vertical accuracy is $15 \mathrm{~cm}$. Point cloud data DEM (Digital Elevation Modell) resulting from measurements with LiDAR can be obtained in the range of 20-100 cm (Shamsi, 2005).

DSM (Digital Surface Model) is one of the data in LiDAR in the form of a topographic elevation model of the earth's surface. In DSM, the data include objects that are on the surface of the Earth, both natural objects, and man-made objects, for example; offices, buildings, ponds, rivers, trees, and vegetation. DSM has a reference to geometric earth (ASPRS, 2007). DEM (Digital Elevation Model) is LiDAR data in the form of point cloud points coordinate to absorb the surface of the earth with geometry. DEM data only display a point cloud in the form of ground where the data do not display earth surface data in the form of buildings, rivers, ponds, vegetation, and other elements. DEM data only display elevation data on the earth's surface which are usually able to be processed into contours and slope (Tempfli, 1991).

\section{LiDAR Working Principles}

When observed, although remote sensing systems work together to produce a measurement, the data acquisition process between system components does not work simultaneously at the same time. This will have implications on the results obtained because the system that works is not on one axis of observation. Example of data acquisition was using LiDAR technology. The data acquisition process at LiDAR has complex system components and it does not work simultaneously and is influenced by various biases. LiDAR is a blend of LRF (Laser Range Finder), POS (Positioning and Orientation System) that integrates DGPS (Differential Global Positioning System), IMU (Inertial Measurement Unit) and Control Units (Lohani, 1996 and Istarno, 2011).

\section{Land Cover or Land Use}

Land Cover or known as land use is an element on the surface of the earth. Some examples of land cover are buildings, vegetation, ponds, swamps, lakes, open land and other elements on the surface of the earth that can include land use for agriculture. The use of land itself is information about the scope of natural or artificial agricultural land that exists on the surface of the earth. The use of agricultural land can be classified or grouped according to certain classes which include the types of land use in the area. The existence of information about land use can provide details about the allotment of a land the region included in order to evaluate the planning in land use in a very guided way with land cover; land cover can be done with a visual approach by looking at the object field directly and visual interpretation of satellite imagery in the form of orthophoto which can clearly identify the types of land cover on the surface of the earth. Closure of agricultural land and vegetation classification can be done with Airborne LiDAR technology to 
produce a map of land cover. The use of LiDAR Technology is able to provide accurate results and ease of digitizing with orthophoto data from LiDAR, because LiDAR data can provide orthophoto data very accurately and clearly to distinguish land cover in the area, while the point cloud produced by LiDAR can be used to determine the height and area that dominates the research area (Purwadhi and Sanjoto, 2008).

Peatlands are very acidic, easily broken and irreversible drying so that the productivity of peatlands is very low. On peatland, there are constraints of physical properties, such as peat porosity, and properties that cannot be returned so that peatlands cannot function properly as organic colloids. In addition, peatlands have very low base saturation, and the micro and macronutrients available for plants are very low. Plant types that can live in peatland are oil palm plants that can be tolerant of high acidity (Hardjowigeno, 1995).

The purpose of this study was to apply Airborne LiDAR technology along with interpretations in the field of agriculture, especially in land cover vegetation mapping with data from $\mathrm{LiDAR}$ results.

\section{MATERIALS AND METHODS}

Equipments and materials needed in this study were computers with the specifications of; 16GB RAM, AMD FX (TM) -8150 Eight-Core Processor, Windows 8 64bit Operating System, Global Mapperv 19 (64 bit), ArcGIS v 10.2, Google Earth Pro. The data needed in this study were DEM in the form of .las files, DSM in the form of a file. las, CHM in the form of file.tif and Orthophoto Jambi in the form of a .ecw file. Sources of data obtained for this study were Digital Aerial Photography, Recording December 1, 2017 - January 1, 2018, LiDAR Data, Recording December 1, 2017 - January 1, 2018, Digital Topographic Maps, Scale 1: 50,000, Geospatial Information Agency, 2015,
Digital Map of Administrative Limits, the Central Statistics Agency of 2016.

The data acquisition process in LiDAR was done by special aircraft having been perforated at the bottom to fire active waves towards the earth's surface waves, infrared, after the Earth with infrared waves object on the earth's surface and then reflected back to the system and will generate data acquisition in the form of point cloud points that have $\mathrm{x}, \mathrm{y}$ and $\mathrm{z}$ coordinates. The data were recorded continuously using the computer provided (Johnson, 2009).

The data needed in this study were from LiDAR data in the form of DEM (data digital Elevation Modell), DSM (Digital Surface Modell), CHM (Crown Hight Modell)processed using Global Mapper software which was then digitized using ArcGIS v 10.2 software which will produce a land cover map along with vegetation classification and density. Therefore, the presence of LiDAR can help in the classification of vegetation and land cover easily.

DEM data can be obtained and map making can be done in several ways, such as: done manually with direct measurements in the field, the establishment of point cloud with LiDAR technology), IFSAR (technology Interferometric Synthetic Aperture Radar), besides SRTM satellite imagery (Shuttle Radar Topography Mission) and ASTER (Advanced Spaceborne Thermal Emission and Reflection Radiometer) (Baitullah, 2015).

\section{LiDAR technology Field}

Data collection techniques used the airborne LiDAR method with GPS installation so as to make point cloud coordinate $x, y$, and $z$. The LiDAR system is a combination of a receiver sub-system on the system (receiver) with laser light infrared that will send optical pulses to reflect the signal again after the earth surface objects can automatically be 
received back into information by the sub receiver system (Figure 1).

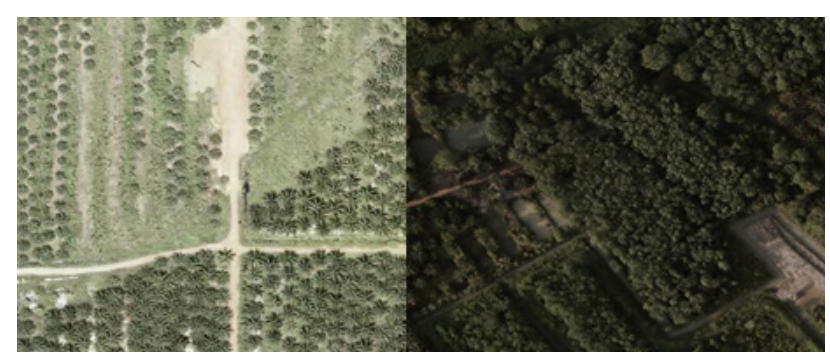

Figure 1. Results of Orthophoto LiDAR are crosschecked in the field, oil palm plantation (left), and rubber plantation (right).

Classification of land cover in this study was based on the key identification of land cover classification by the Geospatial Information Agency (BIG). Classification on this land cover using the visual interpretation method was by looking at objects in data orthophoto produced from LiDAR visually, then digitizing them according to the class of land cover that has been determined as the basis of the previous reference.

The method of classification of land cover with remote sensing technology in visual interpretation method of remote sensing is a technique to obtain information by interpreting object shapes, hues, colors, textures, patterns, and sizes, both qualitatively and quantitatively, based on knowledge and experience of humans. Making land cover class by digitizing directly on LiDAR in the form of orthophoto or satellite image data applied ArcGIS software version 10.2 installed on the computer. When digitizing with the .shp file extension land cover classes were classified based on visuals such as examples; forests, plantations, settlements, elements of water, ponds, rice fields, and other elements

Data processing was carried out by starting with collecting DEM and DSM data (Duantari and Cahyono, 2017). Both data would produce CHM using the formula CHM- = DSM-DEM, the CHM Tunas Baru map was used to digitize vegetation density based on altitude. The CHM class was by way of; replace the class on the Custom Shadow menu in the Global Mapper and give a range of 0-1 m yellow, $1-3 \mathrm{~m}$ green, $3-5 \mathrm{~m}$ purple $5-60 \mathrm{~m}$ dark blue and more than $60 \mathrm{~m}$ black. For orthophoto data, it is used to cross check and digitize new shoot vegetation classification map types. Then overlaying the density map and classification of vegetation in Tunas Baru village resulted in a map of the land cover of Tunas Baru village (Figure 2).

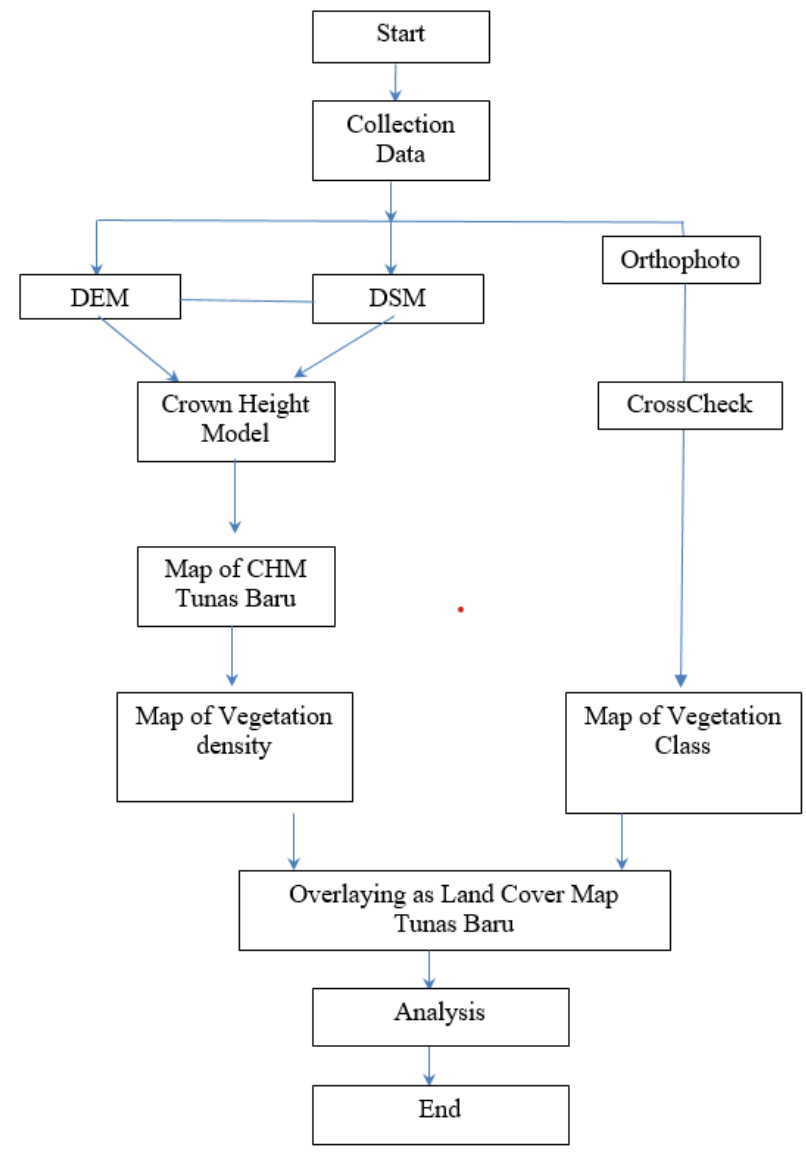

Figure 2. Flow Chart of Making Land Cover Map

\section{RESULTS AND DISCUSSION}

Results of LiDAR Data

The main equipment in this study was laser scanned a Leica product, ALS 70 and RCD 30 model camera. Installation of server equipment was placed on a single engine aircraft that is the Pilatus Porter PC6. ALS 70 which can produce 500,000-second lasers $(500 \mathrm{kHz})$ and 200 scan lines 
per second $(200 \mathrm{kHz})$ and can be operated up to an altitude of 1600 meters above ground level. Leica RCD 30 is a metric mapping camera that has a sensor size of $8956 \times 6708 \mathrm{~mm}$ with a frame rate capability of up to 1 second. Pilatus Porter PC6 a single-engine aircraft has a speed of 151 knots and cruising power of $1050 \mathrm{~km}$, equivalent to a travel time of 3 hours 45 minutes at high speed (Figure 3).

In the process of data acquisition using LiDAR

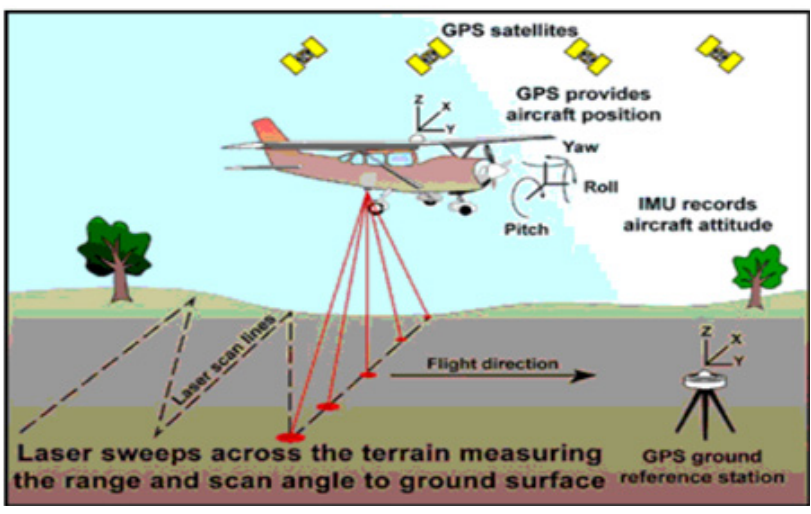

Figure 3. Working Principle of LiDAR (Nawangsidi, 2009)

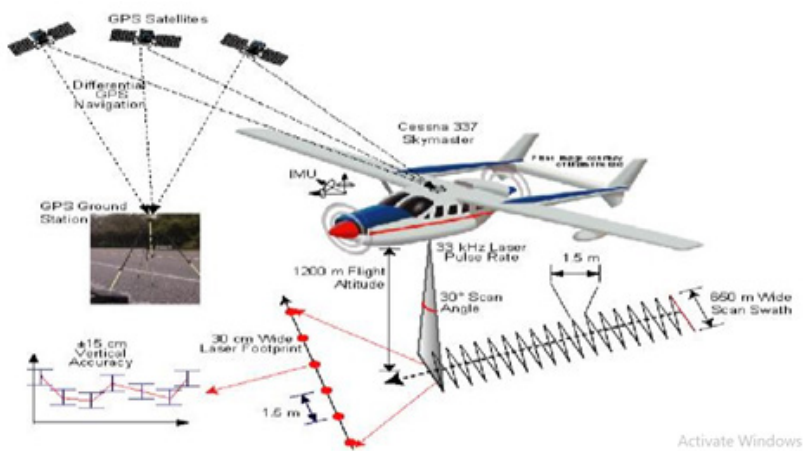

Figure 4. Representation of LiDAR Technology Data Acquisition (Putra, 2016)

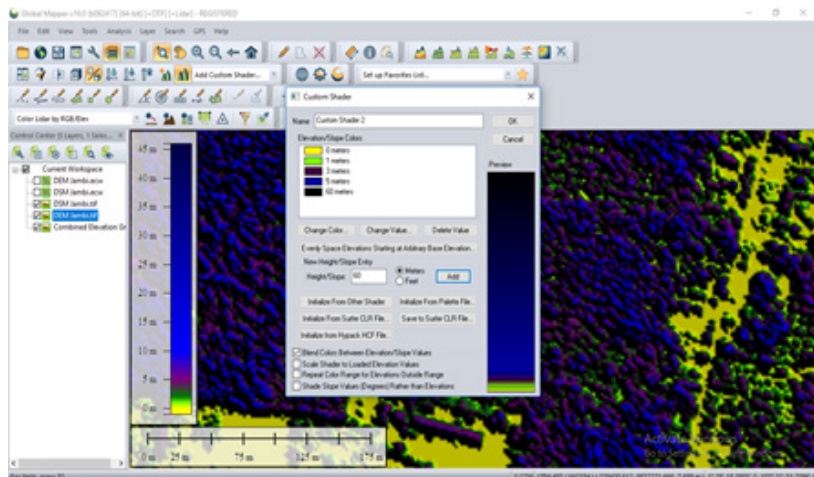

Figure 5. CHM Elevation Class Vegetation technology, laser scanning must be based on careful planning of mathematical models and be able to meet high precision requirements. For laser scanning careful terrestrial calibration, it is also needed to improve the geometric quality of the results of the data acquisition process. GPS (Global Positioning System) is a satellite technology that is used to determine the coordinates and position of a moving vehicle with high accuracy. Sensors in this system were determined by altitude along with the distance between the angle of the sensor and the object points on the surface of the earth, so that it can track or determine the position of the object accurately. An interesting characteristic of the laser sensor in LiDAR technology is that it obtains a density rule at each point in a given unit area which is set and regulated by the frequency of the signal strength of the object (Figure 4) (Pfeifer \& Christian, 2007).

In this research, LiDAR technology can be used for land cover and vegetation classification by utilizing data in LiDAR, which are DEM, DSM, and Orthophoto data. The land Cover was guided by orthophoto because orthophoto is aerial photo data that can be used for accurate analysis and digitization of land cover types, for example, the ability to distinguish oil palm plantations and rubber plantations based on their visual interpretation. At the same time the DEM data where are used to grind to get the CHM data results that can be used to determine the class of vegetation density based on height according to the color differences. Therefore, LiDAR data can make it easier to determine the class of land cover and density based on the height of vegetation.

\section{Key Identification of Density Class and Vegetation}

The classification map of land cover can be obtained from the results of LiDAR data in the form of air orthophoto, while the vegetation density was 


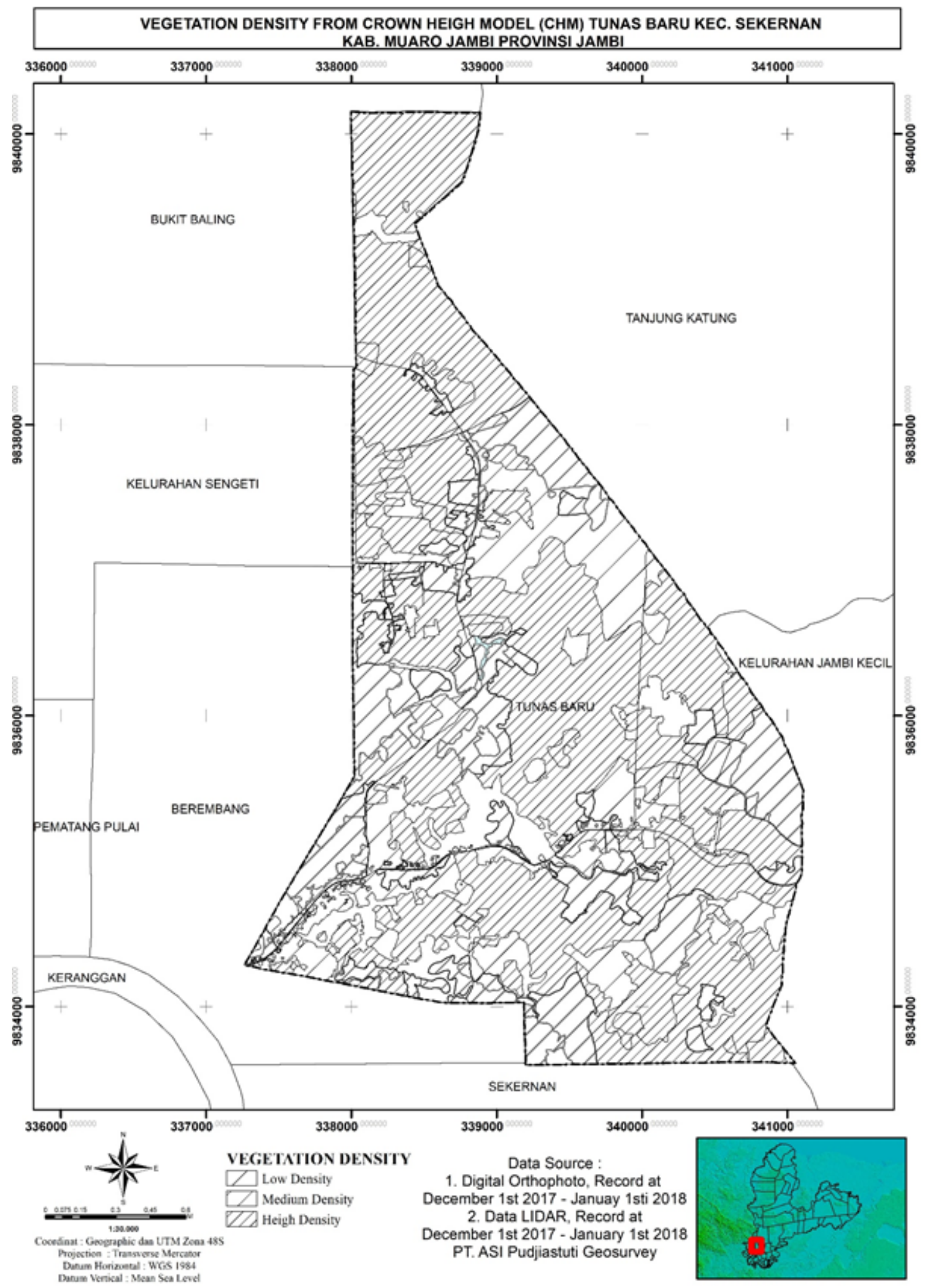

Figure 6. Result of Vegetation Density Digitation 
Planta Tropika: Jurnal Agrosains (Journal of Agro Science) Vol. 7 No. 1 / February 2019

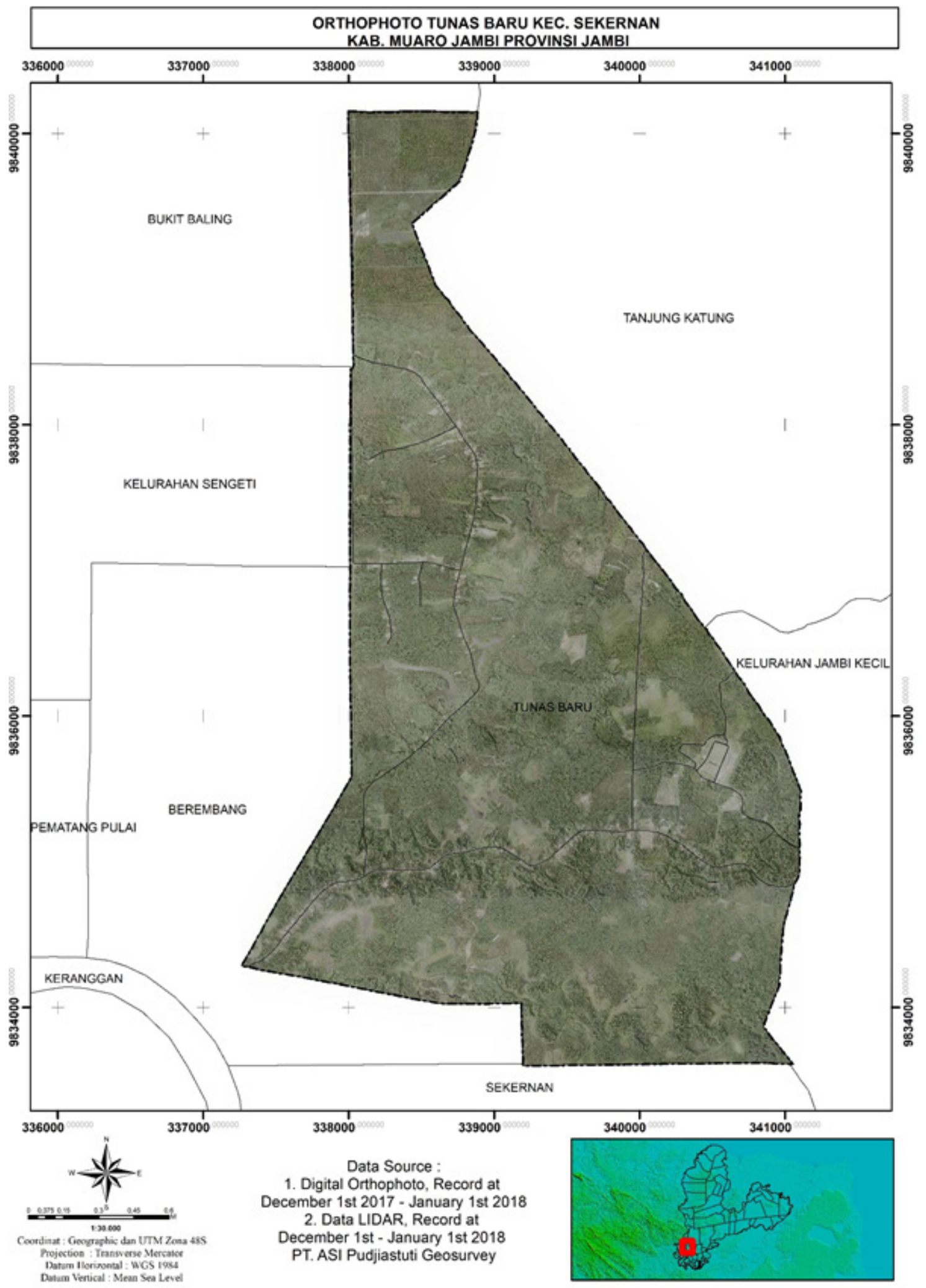

Figure 7. Result of Orthophoto 


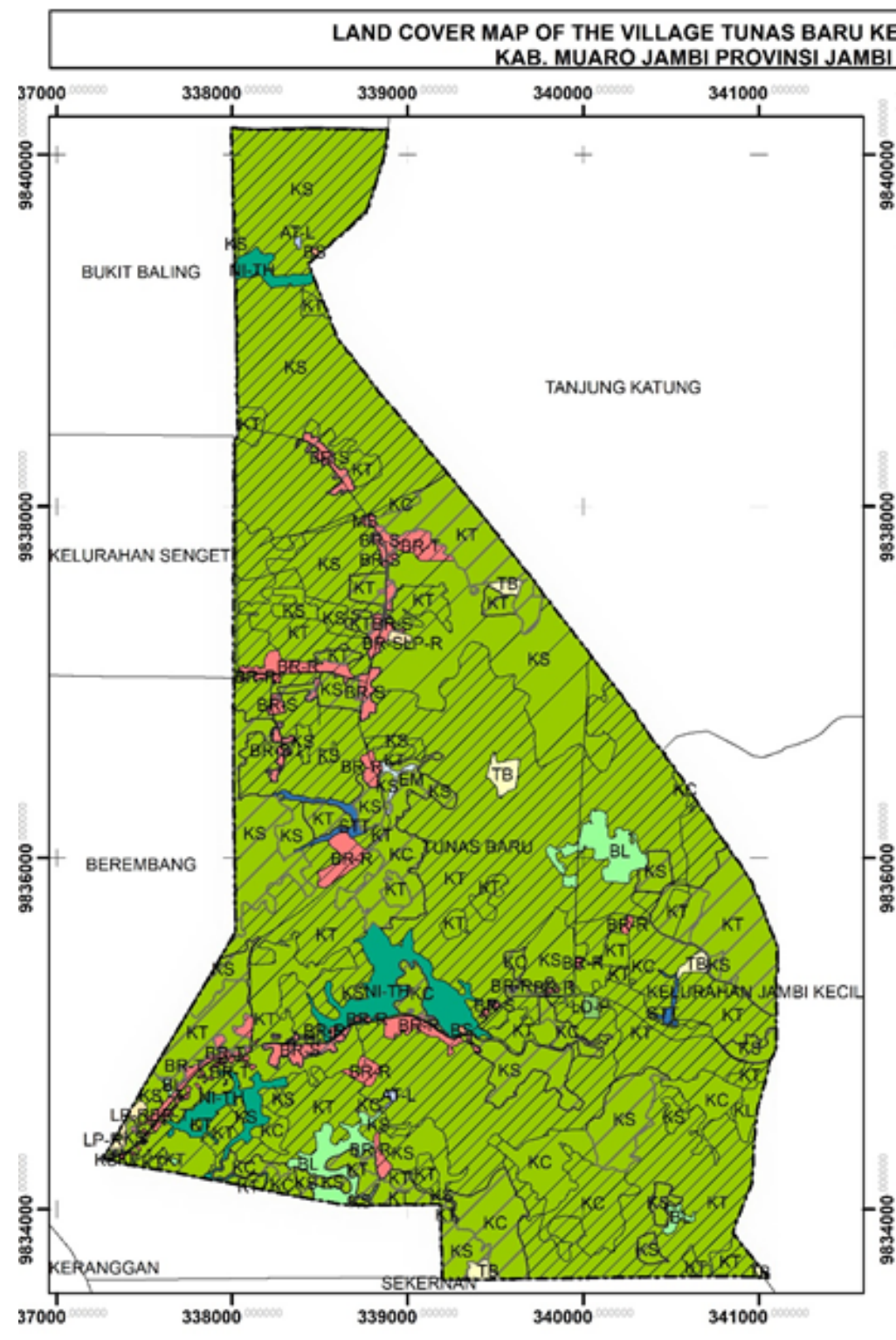

CODE

Cultivating Vegetation KT : Rubber Plantation KS: Oil Palm Plantation

Housing

BR-T : High density residential village buildings BR-S : Medium density residential village buildings $\mathrm{KC}$ : Blend Plantation $\mathrm{KL}$ : Other Plantation BR-R : Low density residential village buikdings Association of residential / Land building Open Land TB : Open Land Fields LD-P : Fields/Moor

Rice Fields Grass Fields

Body of Waters

FM : Deum

Al-L : Pool

NI-TH : Rice paddy non irigation Public lasilitic

Natural Vegetation MS : Mosque

SM : Bush

BL: Scrub

Industry, Service, Ultility, or office

BS : Instead of building a settlement has not been specilied

LEGEND

NATURAL VEGETATION

Bush/Scrub

Scrub

\section{CULTIVATING VEGETATION}

- Plantation/Garden

Rice Fields

Sawah

OPEN LAND

Nature

$\square$ Open Land

LAND BUILDING

Housing

Housing

Cultivation/Public

Mosque

IIIGIIWAV

--- Administrative Boundarics

\section{CULTIVATION}

$\square$ Grass Fields

\section{BODY OF WATERS \\ \begin{tabular}{ll} 
River \\
Dam \\
Pool \\
\hline
\end{tabular}}

VEGETATION DENSITY

$\square$ Low Density

$\square$ Medium Density

VD High Density

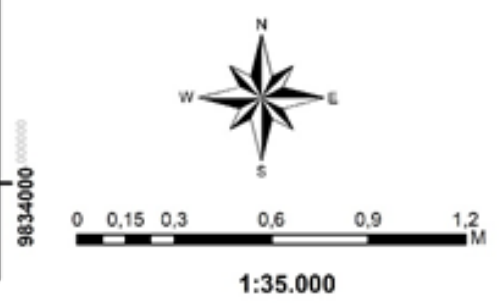

Coordinate : Geogralhic dan UTM 7ona 48S Projection : Transverse Mercator Datum Horizontal : WGS 1984

Datum Vertical : Mean Sea Level

Figure 8. Map of land cover for Tunas Baru Village

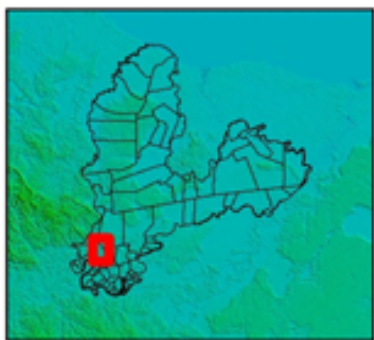


obtained from the results of the DSM and DEM data processing into CHM (Crown Height Model) data and then digitizing them based on color differences. (Figure 6). Orthophoto is used to digitize and identify the classification of vegetation types on land cover (Figure 7). Identification of vegetation and land cover buildings was based on BIG object keys (Geospatial Information Agency). In general, Jambi Province is dominated by widespread forests, but the land use is based on the results of LiDAR data in the Tunas Baru village, Sekernan, Muaro Jambi, Jambi, which has been dominated by many plantations with dominating plantations are rubber plantations. The map results can be seen in (Figure 8). In addition, there is also a function of land for residential buildings.

The benefits of maps of land use in general are: (1) to know the development of land use in an area, (2) to utilize it as a guide in a more structured landuse planning, (3) to know the type of agricultural land use, (4) to assess the relationship between social conditions and physical appearance of land cover on the surface of the earth (Suharyadi, 2001).

The use of agricultural land provides information that can be known by the community to be used for land evaluation and land planning. Land use can be in the form of agricultural, residential, touristic or industrial land, while land cover itself is a natural or an artificial vegetation cover on the surface of the earth. Land cover provides information about the types and elements of the land. Land cover or the use of agricultural land can change according to the function of land carried out by humans (Lillesand \& Kiefer, 1990).

Vegetation density can be determined based on height by processing gridding of DEM data and DSM data using Global Mapper software; in the Combine Terrain Option dialog box, for "Select First Elevation Layer (s) to Combine/Compare", select DSM.tif, while in the second layer select DEM. tif. On the XY axis, choose a sample spacing of 2 meters. Then click "OK" (Figure 5). The determination of the CHM Class is by replacing the class on the Custom Shadow menu in the Global Mapper and giving a range of $0-1 \mathrm{~m}$ yellow, $1-3 \mathrm{~m}$ green, 3-5 m purple $5-60 \mathrm{~m}$ dark blue and more than 60 $\mathrm{m}$ black. Subsequently, CHM data were generated and manually digitized in ArcGIS v 10.2 software How to read maps; The legendary composition of each mapping unit consists of color elements, codes and shading patterns. The color shows the land cover group; the code shows the type of land cover; and the shading pattern shows the vegetation density/settlement.

\section{Distribution of vegetation types as land cover}

Land Cover in agriculture is divided into two large groups of land, which are garden vegetation, and non-garden vegetation. Comparison of the area of accumulated land cover of vegetation and non-vegetation can be seen from the circumference of the circumference, that the land cover of garden vegetation dominates with an area of 262.1 ha, while non-vegetation of the garden is only 66.87 ha. In Tunas Baru Village, Sekernan District, Muaro Jambi Regency, Jambi Province, the dominance of the land cover is in the form of vegetation plantations. For more complete information, see (Figure 9).

Based on the diagram of land cover of plantation vegetation, rubber plantations have the highest total area of 113.8 ha and have the widest high density. This can show that rubber plants grow well, the second plantation commodity is an oil palm plantation with an area of 96.79 ha and has the widest medium density. This is because in Tunas Baru Village, Sekernan District, Muaro Jambi Regency, Jambi, it is dominated by acidic peatlands, while rubber and oil palm are tolerant of acid soils, which generally can grow and develop 


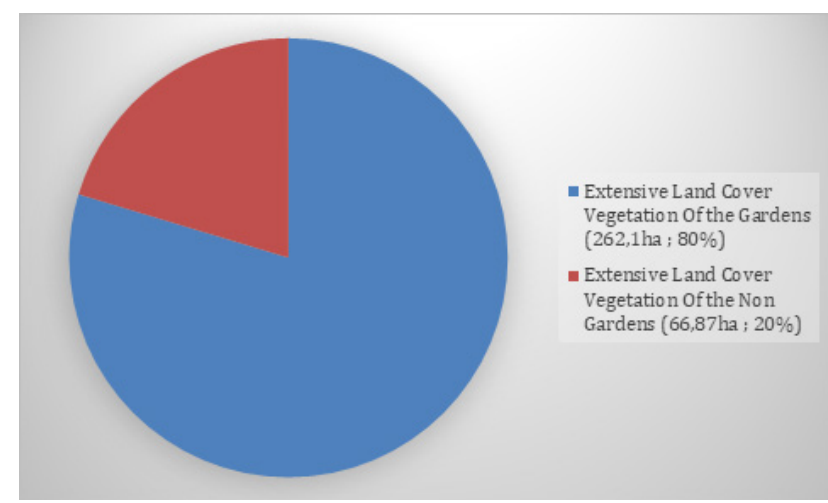

Figure 9. Vegetation and non-garden vegetation area in the research location

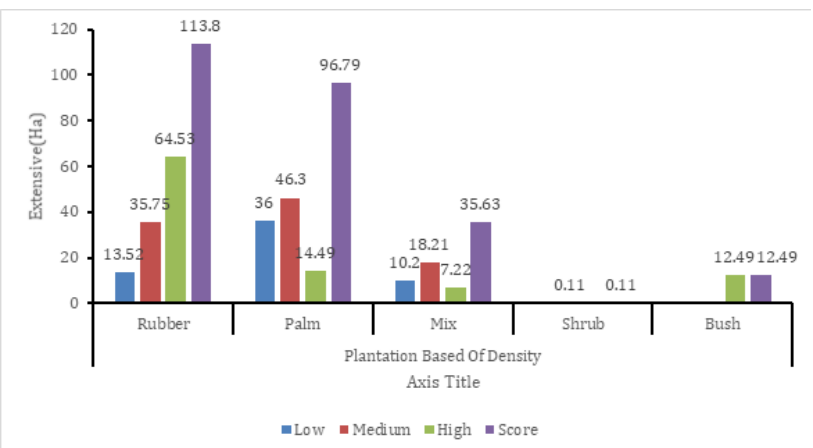

Figure 10. Closure of Plantation Vegetation Based on Density

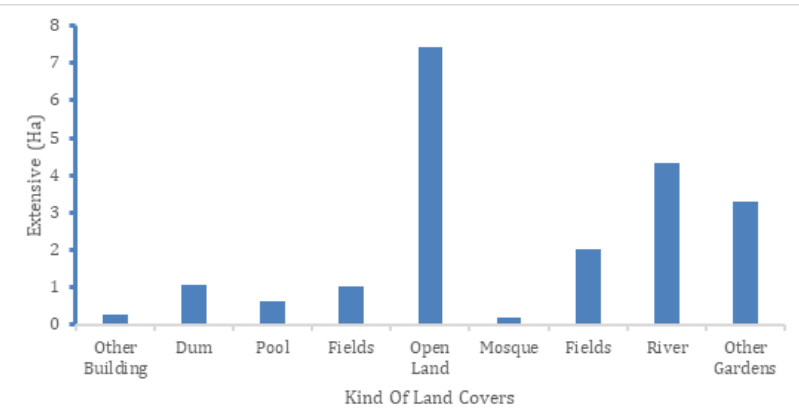

Figure 11. Non-Vegetation Land Cover

by surviving on peat land. Shrubs are land cover in the form of plants that grow naturally with an average height of less than 2 but more than $50 \mathrm{~cm}$; some are woody, and some are not. The thicket is a formation or structure of vegetation in the form of a collection of shrubs with a height of between 50 $\mathrm{cm}$ to $2 \mathrm{~m}$, which is dominated by woody vegetation interspersed with very short trees with the height of $<=5 \mathrm{~m}$. Other gardens are plantations with annual plants (trees) of different types of species that have been previously specified. Mixed gardens are dry land (not rice fields) planted with annual crops (trees) combined with annual crops. It can be seen in (Figure 10).

In the non-vegetation land cover, the population has the highest area of 42.21 ha. Other land covers can also be seen in the diagram of non-vegetation land cover. It can be seen in the Figure (Figure 11).

\section{CONCLUSION}

The results of LiDAR can be in the form of DEM, DSM, and orthophoto. Data to obtain a ground cover map are required in the form of DEM, DSM and orthophoto data which are then processed and used as CHM data. Furthermore, the digitization process in making maps was facilitated.

For more details, orthophoto data were used as digitization of vegetation type and type of land cover based on the appearance of the photo, and it was done digitally manually. AT the same time CHM data were obtained from DEM and DSM data which was used to determine vegetation density based on height classes that have been arranged in different colors by CHM results classified, which were digitized based on color differences in the same way.

The map of dominant land cover in Tunas Baru Village, Sekernan District, Muaro Jambi Regency, in the dominant agricultural sector, shows oil palm plantations and rubber plantations. This can be shown from the orthophoto appearance that a lot of rubber and oil palm plants are quickly cultivated from medium and low high densities. In addition, rubber and oil palm plantations have an important economic role in the surrounding community.

The LiDAR application has a very important role in surveys and mapping because it has an accurate level of research. The use of LiDAR in agriculture, especially in plantations, starts from 
the management of plans for turning gardens into planted plantations, land cover maps, which can also be used as an evaluation of plantation development in that area.

\section{ACKNOWLEDGMENT}

PT ASI Pudjiastuti Geosurvey supported this research. Acknowledgment is conveyed to the company staff who have helped carry out the research and preparation process in writing papers.

\section{REFERENCES}

Agus, F. and Subiksa, IGM 2008. Peatlands: Potential for Agriculture and Environmental Aspects. Soil Research Institute and the World Agroforestry Center (ICRAF). Bogor. Indonesia.

Baitullah MAA. 2015. Utilization of LiDAR Technology in Analysis of Flood Inundation due to River Overflow Based on Simulation of Hydrodynamic Models. Journal of Engineering Info. Vol 16 No. 1: 21-32.

ASPRS, 2007, Digital Elevation Model Technologies and Applications: The DEM Users Manual, 2nd Edition, edited by David F. Maune, Bethesda, Maryland.

Duantari N., Cahyono BA 2017. Comparative Analysis of DTM (Digital Terrain Model) from LiDAR (Light Detection and Ranging) and Aerial Photographs in Making Contours of the Map of Rupa Bumi Indonesia. It's Technical Journal. Vol. 6. No. 2: (2301-9271).

Jambi Province Plantation. 2010. 2006-2010 Strategic Plan for Jambi Province. Jambi Provincial Plantation Office, Jambi

Hardjowigeno S. 1995. Suitability of Indonesian peat soils for agriculture development. in Rieley and Page (Eds) Biodiversity and
Sustainability of Tropical Peatland. Proceedings of the International Symposium on Biodiversity, Environmental Importance, and Sustainability of Tropical Peats and Peatlands. Palangka Raya, 4 - 8 September 1995. p 327-334

Istarno. 2011. Establishment of Digital Elevation Model From LiDAR Data and Its Interpretability for Land Cover Objects in Nganjuk KertosonoCorridor. Gadjah Mada University. Yogyakarta.

Johnson, LE, 2009. Geographic Information Systems in Water Resources Engineering. CRC Press. Florida.

Lillesand and Kiefer. 1990. Remote Sensing and Image Interpretation. Faculty of Geography. Gadjah Mada University. Yogyakarta.

Lohani, B. 1996. Airborne Altimetric LiDAR: Principle, Data Collection, Processing and Applications. Department of Civil Engineering, India.

Nawangsidi, Dipo. 2009. Airborne Altimetric LiDAR; Applications and Problems. Geodesy \& Geomatics Engineering Study Program, ITB Earth Sciences and Technology Faculty.

Pfeifer $\mathrm{N}$ and Briese C. 2007. Laser Scanning Principles and Applications. Institute of Photogrammetry and Remote Sensing. Vienna University of Technology. Austria.

Purwadhi SH, Sanjoto TB. 2008. Introduction to Interpretation of Remote Sensing Images. Jakarta: National Aeronautics and Space Institute and Semarang State University.

Putra, IWE 2016. Working System of Laser Sensors on LiDAR. Journal of Geography Education, FHIS, UNDIKSHA. Vol. 17. No. 1.

Shamsi, UM, 2005. GIS Applications for Water, Wastewater, and Stormwater Systems. CRC Press. Florida.

Suharyadi. 2001. Remote Sensing for City Studies. Yogyakarta: Faculty of Geography, Gadjah Mada University.

Tempfli, K. 1991. DTM and differential modeling. In Suharyadi, R., Sapta, B., Purwanto, TH, Rosyadi. RI, Farda, NM, Wijaya, MS, 2012. Practical Guidelines for Geographic Information Systems: Spatial Modeling. Yogyakarta: Faculty of Geography, Gadjah Mada University. 